\title{
Carnauba wax coating preserves the internal quality of commercial eggs during storage
}

\section{Revestimento com cera de carnaúba preserva a qualidade interna de ovos comerciais durante $o$ armazenamento}

\author{
Cinthia Eyng ${ }^{1 *}$; Kelly Cristina Nunes ${ }^{2}$; Paula Toshimi Matumoto-Pintro ${ }^{3}$; \\ Ana Carolina Pelaes Vital'; Rodrigo Garófallo Garcia5; Lorena Mari Sanches ${ }^{6}$; \\ Nilton Rohloff Junior ${ }^{7}$; Karine Isabela Tenório ${ }^{8}$
}

\section{Highlights}

We studied the effects of carnauba wax coating on quality and lipid oxidation of eggs.

Carnauba wax coating is able to maintain the internal quality of eggs during storage.

The effects of carnauba wax coating were most evident in eggs kept at $25^{\circ} \mathrm{C}$.

Carnauba wax coating did not minimize the oxidative processes in the egg yolk.

\begin{abstract}
The objective of this study was to evaluate the internal quality and lipid oxidation of eggs coated with a carnauba wax-based product at different concentrations and stored for up to 28 days under two temperatures. For analysis of internal quality, the eggs were assigned to a completely randomized $3 \times 4$ factorial design (uncoated eggs (control); eggs coated with carnauba wax at $12 \%$ concentration (Aruá ${ }^{\oplus}$; eggs coated with carnauba wax at 15\% concentration (Aruá ${ }^{\circledR}$ ); four storage periods - 7, 14, 21, and 28 days). Fifteen eggs from each treatment were evaluated in each storage period, with each egg representing one replicate, i.e., 300 eggs per storage temperature $\left(10\right.$ and $\left.25^{\circ} \mathrm{C}\right)$. Egg weight loss, yolk percent (\%), albumen percent (\%), Haugh unit, yolk index, and specific gravity were calculated. Lipid oxidation of the egg yolk was

1 Profa Dra, Postgraduate Program in Zootechnics, Western Paraná State University, UNIOESTE, Marechal Cândido Rondon, PR, Brazil. E-mail: cinthiaeyng@hotmail.com

2 Dra in Zootechnics, State University of Maringá, UEM, Maringá, PR, Brazil. E-mail: kcnunes@live.com

3 Profa Dra, Postgraduate Program in Zootechnics, UEM, Maringá, PR, Brazil. E-mail: ptmpintro@gmail.com

${ }^{4}$ Dra in Feed Science, UEM, Maringá, PR, Brazil. E-mail: ana_carolv@hotmail.com

5 Prof. Dr., Postgraduate Program in Zootechnics, Federal University of Grande Dourados, UFGD, Dourados, MS, Brazil. E-mail: rodrigogarcia@ufgd.edu.br

${ }^{6}$ PhD Student of Postgraduate Program in Zootechnics, Faculty of Agricultural Sciences, UFGD, Dourados, MS, Brazil. E-mail: lo.orena@hotmail.com

7 PhD Student of Postgraduate Program in Zootechnics, UNIOESTE, Marechal Cândido Rondon, PR, Brazil. E-mail: nilton_rohloff_8@hotmail.com

8 Master Student of Postgraduate Program in Zootechnics, UNIOESTE, Marechal Cândido Rondon, PR, Brazil. E-mail: karinetenorio@gmail.com

* Author for correspondence
\end{abstract}

Received: May 27, 2020 - Approved: Jan. 07, 2021 
measured by thiobarbituric acid reactive substances (TBARS), using 10 eggs at time 0 (fresh) and 30 eggs in each storage period $\left(7,14,21\right.$, and 28 days), in triplicate, under only one storage temperature $\left(25^{\circ} \mathrm{C}\right)$. $\mathrm{A}$ total of five pools, consisting of two eggs each, were used for each treatment. Each pool was considered a replicate, and each treatment consisted of five replicates. The weight loss of the eggs stored at $10^{\circ} \mathrm{C}$ and $25^{\circ} \mathrm{C}$ during the storage period was, on average, $46.1 \%$ and $37.3 \%$ lower for the eggs coated with carnauba wax than in uncoated eggs, respectively. Overall, coated eggs, regardless the concentration of the wax (12 or $15 \%)$ had higher Haugh units, specific gravity, and yolk index than uncoated eggs, in both temperatures (10 and $25^{\circ} \mathrm{C}$ ). Uncoated and coated eggs showed similar lipid oxidation values regardless of the storage period. On the other hand, eggs coated with solutions containing $15 \%$ wax showed less oxidation than eggs coated with $12 \%$ wax. The coating of commercial eggs with carnauba wax, both at concentrations of 12 and $15 \%$, was effective in maintaining their internal quality during storage at both storage temperatures (10 and $25^{\circ} \mathrm{C}$ ). Eggs stored at $25^{\circ} \mathrm{C}$ had lower quality traits during storage compared with eggs kept under refrigeration. Coating eggs with wax did not minimize the oxidative processes in the egg yolk.

Key words: Edible coating. Haugh unit. TBARS. Wax.

\section{Resumo}

O objetivo deste estudo foi avaliar a qualidade interna e a oxidação lipídica de ovos revestidos com um produto a base de cera de carnaúba, com diferentes concentrações, e estocados por até 28 dias sob condições de duas temperaturas. Para as análises de qualidade interna, os ovos foram distribuídos em um delineamento inteiramente casualizado em esquema fatorial $3 \times 4$ (ovos não revestidos (controle); ovos revestidos com cera de carnaúba a 12\% (Aruá ${ }^{\circledR}$ ); ovos revestidos com cera de carnaúba a 15\% (Arua®); quatro períodos de estocagem - 7, 14, 21 e 28 dias). Quinze ovos de cada tratamento foram avaliados em cada período de estocagem, sendo considerado cada ovo uma repetição, totalizando 300 ovos por temperatura de estocagem $\left(10\right.$ e $25^{\circ} \mathrm{C}$ ). Para cada período foram calculados a perda de peso dos ovos, porcentagem de gema, porcentagem de albúmen, unidade Haugh, índice de gema e gravidade específica. A oxidação lipídica da gema dos ovos foi mensurada através das substâncias reativas ao ácido tiobarbitúrico (TBARS), utilizando 10 ovos para o tempo 0 (frescos) e 30 ovos em cada período de estocagem (7, 14, 21 e 28 dias), em triplicata, sob a temperatura de estocagem de $25^{\circ} \mathrm{C}$. Um total de cinco pools, consistindo de dois ovos cada, foram utilizados para cada tratamento. Cada pool foi considerado uma repetição possuindo cada tratamento cinco repetições. A perda de peso dos ovos estocados a $10^{\circ} \mathrm{C}$ e a $25^{\circ} \mathrm{C}$ durante o armazenamento foi, em média, $46,1 \%$ e 37,3\% mais baixo para os ovos revestidos com a cera de carnaúba em comparação aos ovos não revestidos, respectivamente. De maneira geral, os ovos revestidos, independentemente da concentração da cera (12 ou 15\%) apresentaram maior unidade Haugh, gravidade específica e índice de gema comparado aos ovos não revestidos, em ambas as temperaturas (10 e $25^{\circ} \mathrm{C}$ ). Os ovos não revestidos e revestidos apresentaram valores de oxidação lipídica similares independentemente do período de estocagem. Por outro lado, ovos revestidos com soluções contendo 15\% de cera demonstraram menor oxidação do que os ovos revestidos com cera a $12 \%$. O revestimento de ovos comerciais com cera de carnaúba, em ambas as concentrações de 12 e 15\%, foi efetivo em manter a qualidade interna dos ovos durante o armazenamento em ambas as temperaturas $\left(10\right.$ e $\left.25^{\circ} \mathrm{C}\right)$. Ovos estocados a $25^{\circ} \mathrm{C}$ apresentaram menor qualidade comparado aos ovos mantidos sob refrigeração. O revestimento dos ovos com a cera não minimizou os processos oxidativos na gema do ovo.

Palavras-chave: Cera. Revestimento comestível. TBARS. Unidade Haugh. 


\section{Introduction}

The growing concern of consumers about a nutritionally balanced and healthy diet has increased the consumption of egg protein in recent years. Eggs are a source of highquality protein that contains nine essential amino acids and elements such as iron, phosphorus, vitamins, and essential fatty acids (Caner \& Yüceer, 2015; Figueiredo et al., 2014). Moreover, the ratio of essential to total amino acids in eggs is higher than $40 \%$ and, within the recommended levels assigned by the Food and Agriculture Organization and World Health Organization (Sun, Liu, Yang, \& Xu, 2019).

However, eggs are perishable and start deteriorating immediately after being laid. Losses in egg quality involve changes in chemical, physical, biological, and functional parameters (Hidalgo, Lucisano, Comelli, \& Pompei, 1996), which impair not only the acceptability of the product by the consumer but also its use by the food industry. Internal egg quality may particularly deteriorate under inappropriate storage conditions such as inadequate temperature, humidity, presence of CO2, and long storage periods (Chung \& Lee 2014; Samli, Agma, \& Senkoylu, 2005).

Eggs naturally have a protective coating composed of glycoproteins and minor components such as hydroxyapatite crystals, polysaccharides, and lipids (Wellman-Labadie, Picman, \& Hincke, 2008), reducing bacterial contamination and water loss through the eggshell. Many proteins present in the eggshell cuticle, including lysozyme $\mathrm{C}$, ovotransferrin, ovocalyxin-32, cystatin, and ovoinhibitor have antimicrobial activity (Rose-Martel, Du, \& Hincke, 2012). Therefore, the cuticle acts as both a physical and chemical barrier by restricting water loss through the eggshell and preventing the penetration of undesirable microorganisms, respectively. Both processes are essential for preserving egg quality.

However, the legislations of several countries, including the USA, Australia, Japan (Hutchison et al., 2004), and Brazil (MAPA, 1990), determine that commercial eggs must be washed and sanitized before being sold. Although these procedures can reduce the microbial load on the eggshell, they may also damage the cuticle (Liu, Chen, Wu, Lee, \& Tan, 2016). As a result, the eggs become susceptible to unfavorable conditions in terms of internal quality and bacterial penetration (Gole et al., 2014; Wardy, Torrico, No, Prinyawiwatkul, \& Saalia 2010). Bacterial contamination is approximately $40 \%$ higher in eggs with damaged cuticles than in eggs with intact cuticles (Wilson, 2017).

The search for natural coatings that can seal the eggshell pores and mitigate deteriorative processes has increased due to the growing concern towards preserving egg quality during storage. These coatings are developed from polysaccharides, proteins, lipids, and combinations of thereof (Falguera, Quintero, Jiménez, Muñoz, \& Ibarz, 2011). Among the products available are mineral oils, soy protein, whey protein, gluten, chitosan, corn-zein protein, and cellulose-based products, which are effective in reducing water loss and microorganism penetration through the egg pores (Almeida, Schneider, Yuri, Machado, \& Gewehr, 2015; Molavi, Behfar, Ali Shariati, Kaviani, \& Atarod, 2015; Yuceer \& Caner, 2014).

Carnauba wax, which is extracted from the leaves of a Brazilian tropical palm tree, Copernicia cerifera, has been extensively 
used in its refined form for coating fruits and vegetables and is considered safe for human consumption (Dou, 2004). The coating of fruits and vegetables with carnauba wax, in combination with additives such as cassava starch and glycerol, has shown satisfactory results in maintaining the quality and increasing the shelf life of products (Bhattacharjee \& Dhua, 2018; Chiumarelli \& Hubinger, 2014; Yang, Li, \& Lu, 2018). Despite the evidence, no study to date has evaluated the use of carnauba wax to coat commercial eggs.

Based on this information, we hypothesized that coating eggs with carnauba wax can maintain their internal quality and stabilize lipid oxidation during storage. Therefore, the objective of this study was to evaluate the internal quality and lipid oxidation of eggs coated with a carnauba wax-based product at different concentrations and stored for up to 28 days under two temperatures.

\section{Material and Methods}

\section{Location and experimental design}

The experiment was carried out at the Federal University of Grande Dourados, Dourados, MS, Brazil. A total of 600 and 130 unfertilized white eggs from 35-weekold Bovans White hens were obtained from a commercial farm and used to perform internal quality and lipid oxidation analyses, respectively. To avoid egg cuticle damage which would favor the bacterial contamination, interfering in the evaluation of the effect of carnauba coating, the eggs were collected immediately after being laid and transported to the laboratory. Before the analyses initiated the eggs were screened for defects (crack, breakage, and surface cleanliness).
For analysis of internal quality, the unwashed eggs were weighed, labeled, and assigned to a completely randomized $3 \times 4$ factorial design (uncoated eggs (control); eggs coated with carnauba waxat $12 \%$ concentration (Aruá ${ }^{\circledR}$ ); eggs coated with carnauba wax at $15 \%$ concentration (Aruá $\left.{ }^{\circledast}\right) ;$ four storage periods - 7 , 14,21 , and 28 days). Fifteen eggs from each treatment were evaluated in each storage period $(7,14,21$, and 28 days), with each egg representing one replicate, i.e., 300 eggs per storage temperature $\left(10\right.$ and $\left.25^{\circ} \mathrm{C}\right)$. Egg weight loss, yolk percent (\%), albumen percent (\%), Haugh unit, yolk index, and specific gravity were calculated.

Lipid oxidation of the egg yolk was measured by thiobarbituric acid reactive substances (TBARS), using 10 eggs at time 0 (fresh) and 30 eggs in each storage period (7, 14,21 , and 28 days), in triplicate, under only one storage temperature $\left(25^{\circ} \mathrm{C}\right)$. A total of five pools, consisting of two eggs each, were used for each treatment. Each pool was considered a replicate, and each treatment consisted of five replicates.

\section{Application of edible coating and storage}

Coatings were composed of a commercial carnauba wax with vegetable resin-based solutions (colophony) (Aruá ${ }^{\circledR}$ Comércio e Serviço LTDA, São Paulo, Brazil) at concentrations of 12 and $15 \%$ (\% of soluble components). Eggs were placed on rollers and the solutions were sprayed from a height of 15 cmabove the eggs over the entire surface using a hand sprayer. Care was taken to ensure that each egg had a uniform coating with no visible defects. The control treatment did not receive carnauba wax treatment (uncoated eggs). The 
eggs were air-dried at ambient conditions for approximately $30 \mathrm{~min}$, and were then packed in pulp egg cartons. Cartons were then placed in two different Biochemical Oxygen Demand (BOD)-type climatic chambers according to storage temperature (10 and $25^{\circ} \mathrm{C}$ ), under the same conditions of relative humidity $(70 \%)$, for 28 days.

\section{Egg quality}

The eggs were weighed on day zero and at the end of each storage period, and egg weight loss (\%) was calculated by the difference. After weighing, the eggs were analyzed for specific gravity by flotation in saline solutions of different concentrations (1.060, 1.065, 1.070, 1.075, 1.080, 1.085, and 1.090). The saline solutions were adjusted and calibrated periodically with the aid of a hydrometer.

After the evaluation of specific gravity, the eggs were broken on a flat surface and albumen height as well as yolk height and diameter were determined using a digital caliper. All measurements were taken in the central part of the egg. The Haugh unit was calculated based on the height of the albumen and egg weight, as described by Brant and Shrader (1958). The yolk index was obtained by the relation between its height and diameter.

Subsequently, yolk and eggshell were separated and individually weighed. Albumen weight was calculated by subtracting yolk weight and eggshell weight from egg weight. Yolk percentage and albumen percentage were calculated relative to the total egg weight.

\section{Lipid oxidation in egg yolk}

Determination of TBARS, expressed in milligrams of malondialdehyde per kilogram of yolk (mgMAD.kg-1), was performed according to the methodology adapted from Vyncke (1970). Two grams of the samples were homogenized with $8 \mathrm{~mL}$ of trichloroacetic acid at $15 \%$. Subsequently, the tubes were placed in a homogenizer for 10 minutes and then centrifuged for 20 minutes at 3,000 rpm. Two $\mathrm{mL}$ of the obtained supernatant were homogenized with $2 \mathrm{~mL}$ of TBA solution (1\% TBA, 15\% TCA, and $\mathrm{HCl} 562.5 \mathrm{mM}$ ). The samples were then incubated at $100^{\circ} \mathrm{C}$ for 15 minutes and, after cooling to room temperature, absorbance was measured in a spectrophotometer at $532 \mathrm{~nm}$.

\section{Statistical analyses}

The effects of coating type, storage period, and their interaction were evaluated by analysis of variance. Means were compared by Tukey's test $(P<0.05)$ using $S A S^{\circledR}$ University Edition (2017) (SAS Inst. Inc., Cary, NC, USA).

\section{Results and Discussion}

Egg quality

There was a significant interaction $(\mathrm{P}<$ 0.05 ) between coating type and storage period on egg weight loss and specific gravity in eggs stored at $10^{\circ} \mathrm{C}$ (Table 1). Overall, the sliced data show that although weight loss increased gradually during storage for all treatments, the weight loss in eggs coated with carnauba wax was, on average, $46.1 \%$ lower $(P<0.05)$ than 
that in uncoated eggs. Uncoated eggs had a lower specific gravity after 21 days of storage $(P<0.05)$, whereas coated eggs differed only in the last storage period (28 days). Within each storage period, coated eggs, regardless of the concentration, showed a higher specific gravity than uncoated eggs after 7 days of storage (Table 2). There was a significant effect $(P<0.05)$ of coating type and storage period on Haugh unit and yolk index. Regardless of the storage period, eggs coated with carnauba wax had higher Haugh unit and yolk index values than uncoated eggs. Moreover, the eggs had lower Haugh unit values after 21 days of storage, regardless of the coating type. Yolk percentage and albumen percentage were affected $(P<0.05)$ by the storage period, in which albumen \% decreased and yolk \% increased with increasing storage period (Table 1).

There was a significant interaction $(P<$ 0.05 ) between coating type and storage period on all variables associated with internal quality (weight loss, Haugh Unit, Yolk Index, albumen \%, yolk \%, and specific gravity) in eggs stored at $25^{\circ} \mathrm{C}$ (Table 3). The sliced data show that, within each storage period, coating with carnauba wax decreased $(P<0.05)$ weight loss by 69.4 , $60.6,67.5$, and $58.8 \%$, on average, in eggs stored for $7,14,21$, and 28 days, respectively. Furthermore, coating with solutions containing wax at $15 \%$ was more efficient in reducing egg weight loss up to 21 days, with results similar to those coated with $12 \%$ wax at 28 days. Coated eggs had higher Haugh units at 14 and 21 days and higher yolk index values at 7, 14, and 21 days $(P<0.05)$ than uncoated eggs. At 28 days, eggs coated with carnauba wax at $15 \%$ concentration showed a response similar to that of uncoated eggs for both variables. Coated eggs had higher albumen \% values at 21 and 28 days of storage, but lower yolk $\%$ at 28 days of storage. They also showed a higher specific gravity than uncoated eggs before 21 days of storage, whereas after 28 days, the eggs showed a similar response. There was a gradual increase in egg weight loss (\%) and yolk \% with increasing storage period, regardless of the treatment (coated or uncoated). On the other hand, the remaining variables (Haugh units, Yolk Index, albumen \%, and specific gravity) decreased progressively with increasing storage period (Table 4).

Keeping fresh eggs under refrigeration is a feasible strategy to increase their shelf life, even though this is not possible in many regions and countries. Therefore, the use of edible coating is viable alternative to reduce egg weight loss during storage and to maintain internal egg quality. Different types of coatings, such as mineral oil, beeswax, milk and soy proteins, and chitosan, have proved to be effective in maintaining the quality of eggs during storage (Sharaf Eddin, Ibrahim, \& Tahergorabi, 2019). 
Table 1

Internal egg quality of commercial laying hens coated with different concentrations of carnauba wax and stored at $10^{\circ} \mathrm{C}$, for 28 days

\begin{tabular}{|c|c|c|c|c|c|c|}
\hline Treatments & $\begin{array}{l}\text { Weight } \\
\text { loss (\%) }\end{array}$ & Haugh unit & $\begin{array}{l}\text { Yolk } \\
\text { index }\end{array}$ & $\begin{array}{c}\% \text { of } \\
\text { albumen }\end{array}$ & $\begin{array}{c}\begin{array}{c}\% \\
\text { of yolk }\end{array} \\
\end{array}$ & $\begin{array}{c}\text { Specific gravity } \\
\left(\text { g. }^{-3}\right)\end{array}$ \\
\hline \multicolumn{7}{|l|}{ Edible coating } \\
\hline 0 (control) & 2.55 & $80.69 b$ & $0.377 b$ & 61.59 & 28.78 & 1.062 \\
\hline $12 \%$ wax & 1.38 & $84.50 a$ & $0.393 a$ & 62.31 & 28.09 & 1.074 \\
\hline $15 \%$ wax & 0.97 & $84.31 a$ & $0.401 a$ & 62.05 & 28.39 & 1.074 \\
\hline \multicolumn{7}{|l|}{ Storage Period } \\
\hline 7 days & 0.60 & $84.77 a$ & $0.396 a b$ & $63.45 a$ & $27.29 c$ & 1.077 \\
\hline 14 days & 1.38 & $83.63 a$ & $0.383 b c$ & 62.33ab & $28.10 b c$ & 1.074 \\
\hline 21 days & 1.52 & $86.52 a$ & $0.408 a$ & $61.53 b c$ & $28.72 a b$ & 1.071 \\
\hline 28 days & 3.04 & $77.75 b$ & $0.373 c$ & $60.63 c$ & $29.58 a$ & 1.058 \\
\hline SEM $^{1}$ & 0.019 & 0.433 & 0.001 & 0.141 & 0.124 & 0.001 \\
\hline \multicolumn{7}{|c|}{ ANOVA } \\
\hline Coating (C) & $<0.0001$ & $<0.0001$ & $<0.0001$ & 0.3354 & 0.2853 & $<0.0001$ \\
\hline Period (P) & $<0.0001$ & 0.0233 & $<0.0001$ & $<0.0001$ & 0.0003 & $<0.0001$ \\
\hline Interaction $\mathrm{C} \times \mathrm{P}$ & $<0.0001$ & 0.1912 & 0.2637 & 0.6885 & 0.8220 & 0.0427 \\
\hline
\end{tabular}

Means with different letters within a column are significantly different $(P<0.05)$ after Tukey test.

${ }^{1} \mathrm{SEM}=$ standard error of the mean.

Table 2

Deployment of interaction between coating and storage period on weight loss and specific gravity in eggs from commercial laying hens coated with different concentrations of carnauba wax and stored at $10^{\circ} \mathrm{C}$, for 28 days

\begin{tabular}{|ccccc|} 
& \multicolumn{4}{c|}{ Storage Period (days) } \\
\cline { 2 - 5 } Edible coating & 7 & \multicolumn{4}{c|}{14} & 21 & 28 \\
\hline (control) & $1.06 \mathrm{dA}$ & $2.03 \mathrm{cA}$ & $2.65 \mathrm{bA}$ & $4.47 \mathrm{aA}$ \\
$12 \%$ wax & $0.44 \mathrm{~dB}$ & $1.42 \mathrm{bB}$ & $1.02 \mathrm{cB}$ & $2.65 \mathrm{aB}$ \\
$15 \%$ wax & $0.32 \mathrm{cC}$ & $0.70 \mathrm{bC}$ & $0.88 \mathrm{bB}$ & $2.00 \mathrm{aC}$ \\
\hline & \multicolumn{5}{c}{ Specific gravity $\left({\left.\mathrm{g} . \mathrm{cm}^{-3}\right)}\right.$} \\
\hline (control) & $1.071 \mathrm{aB}$ & $1.067 \mathrm{aB}$ & $1.061 \mathrm{bB}$ & $1.051 \mathrm{cB}$ \\
$12 \%$ wax & $1.080 \mathrm{aA}$ & $1.078 \mathrm{aA}$ & $1.077 \mathrm{aA}$ & $1.060 \mathrm{bA}$ \\
$15 \%$ wax & $1.080 \mathrm{aA}$ & $1.079 \mathrm{aA}$ & $1.075 \mathrm{aA}$ & $1.062 \mathrm{bA}$
\end{tabular}

Means with different lowercase letters within a line are significantly different after Tukey test $(P<0.05)$. Means with different upper letters within a column are significantly different after Tukey test $(P<0.05)$. 
Table 3

Internal egg quality of commercial laying hens coated with different concentrations of carnauba wax and stored at $25^{\circ} \mathrm{C}$, for 28 days

\begin{tabular}{|c|c|c|c|c|c|c|}
\hline Treatments & $\begin{array}{l}\text { Weight } \\
\text { loss (\%) }\end{array}$ & $\begin{array}{l}\text { Haugh } \\
\text { unit }\end{array}$ & $\begin{array}{l}\text { Yolk } \\
\text { index }\end{array}$ & $\begin{array}{c}\% \text { of } \\
\text { albumen }\end{array}$ & $\begin{array}{c}\% \\
\text { of yolk }\end{array}$ & $\begin{array}{c}\text { Specific gravity } \\
\left(\text { g.cm }^{-3}\right)\end{array}$ \\
\hline \multicolumn{7}{|l|}{ Edible coating } \\
\hline 0 (control) & 6.87 & 59.37 & 0.262 & 58.30 & 31.44 & 1.053 \\
\hline $12 \%$ wax & 2.88 & 67.99 & 0.314 & 61.08 & 29.23 & 1.060 \\
\hline $15 \%$ wax & 2.25 & 68.26 & 0.317 & 60.40 & 29.96 & 1.065 \\
\hline \multicolumn{7}{|l|}{ Storage Period } \\
\hline 7 days & 1.41 & 79.06 & 0.365 & 62.47 & 28.16 & 1.069 \\
\hline 14 days & 3.10 & 72.28 & 0.312 & 60.07 & 29.95 & 1.061 \\
\hline 21 days & 4.45 & 59.52 & 0.289 & 59.20 & 30.88 & 1.056 \\
\hline 28 days & 7.03 & 49.27 & 0.226 & 57.97 & 31.84 & 1.051 \\
\hline SEM1 & 0.055 & 0.398 & 0.002 & 0.137 & 0.134 & 0.001 \\
\hline \multicolumn{7}{|l|}{ ANOVA } \\
\hline Coating (C) & $<0.0001$ & $<0.0001$ & $<0.0001$ & $<0.0001$ & $<0.0001$ & $<0.0001$ \\
\hline Period (P) & $<0.0001$ & $<0.0001$ & $<0.0001$ & $<0.0001$ & $<0.0001$ & $<0.0001$ \\
\hline Interaction $\mathrm{C} \times \mathrm{P}$ & $<0.0001$ & 0.0035 & $<0.0001$ & $<0.0001$ & 0.0002 & $<0.0001$ \\
\hline
\end{tabular}

${ }^{1} \mathrm{SEM}=$ standard error of the mean

Carnauba wax, which is extracted from the leaves of a Brazilian tropical palm tree, Copernicia cerifera, has been extensively used around the world for coating fruits and vegetables (Singh et al., 2019; Yang et al., 2018). The incorporation of carnauba wax into foods and its use as an additive and coating material is considered safe by several food safety organizations (Freitas et al., 2019). It is believed that the leaves of this palm are covered by a waxy layer as an adaptation to dry environments. This coating forms a semipermeable barrier to oxygen, carbon dioxide, and water, thereby reducing respiration rates, oxidation reactions, and water loss, thus contributing to food preservation (Falguera et al., 2011). Moreover, coating with carnauba wax enhances the gloss and appearance of foods, increasing customer acceptance.

Carnauba wax was an efficient physical barrier by sealing the pores and reducing the loss of components through the eggshell during storage, confirming our hypothesis about the maintenance of internal egg quality. In our study, the effects were most evident in eggs kept at $25^{\circ} \mathrm{C}$. Many chemical reactions between the internal components of an egg occur soon after laying and during storage, with consequent quality loss. These reactions include the dissociation of carbonic acid, which is a component of the buffer system in 
Table 4

Deployment of interaction between coating and storage period on weight loss, haugh unit, yolk index, albumen, yolk and specific gravity in eggs of commercial laying hens coated with different concentrations of carnauba wax and stored at $10^{\circ} \mathrm{C}$, for 28 days

\begin{tabular}{|c|c|c|c|c|}
\hline \multirow[b]{2}{*}{ Edible coating } & \multicolumn{4}{|c|}{ Storage Period (days) } \\
\hline & 7 & 14 & 21 & 28 \\
\hline & \multicolumn{4}{|c|}{ Weight loss (\%) } \\
\hline 0 (control) & $2.63 d A$ & $5.20 c A$ & 8.09bA & $11.56 a A$ \\
\hline $12 \%$ wax & $0.91 \mathrm{cB}$ & $2.63 \mathrm{bB}$ & $3.11 \mathrm{bB}$ & 4.86aB \\
\hline \multirow[t]{2}{*}{$15 \%$ wax } & $0.70 \mathrm{dC}$ & $1.47 \mathrm{cC}$ & $2.15 b C$ & 4.67aB \\
\hline & \multicolumn{4}{|c|}{ Haugh unit } \\
\hline 0 (control) & $75.42 \mathrm{aA}$ & 63.86bB & $52.25 c B$ & $45.95 \mathrm{~dB}$ \\
\hline $12 \%$ wax & 81.29aA & $73.94 \mathrm{bA}$ & $61.29 c A$ & $56.54 d A$ \\
\hline \multirow[t]{2}{*}{$15 \%$ wax } & $80.47 a A$ & 79.03aA & $65.03 \mathrm{bA}$ & $47.41 \mathrm{cB}$ \\
\hline & \multicolumn{4}{|c|}{ Yolk index } \\
\hline 0 (control) & $0.341 \mathrm{aB}$ & $0.280 \mathrm{bC}$ & $0.239 c \mathrm{C}$ & $0.189 \mathrm{~dB}$ \\
\hline $12 \%$ wax & $0.377 a A$ & $0.315 b B$ & $0.293 b c B$ & $0.272 c A$ \\
\hline \multirow[t]{2}{*}{$15 \%$ wax } & $0.376 a A$ & $0.340 \mathrm{bA}$ & $0.335 \mathrm{bA}$ & $0.218 c B$ \\
\hline & \multicolumn{4}{|c|}{ Albumen (\%) } \\
\hline 0 (control) & $61.88 \mathrm{aB}$ & $60.57 a A$ & $56.71 \mathrm{bB}$ & $54.05 c B$ \\
\hline $12 \%$ wax & $63.94 a A$ & $59.40 \mathrm{bA}$ & $60.58 \mathrm{bA}$ & $60.42 b A$ \\
\hline \multirow[t]{2}{*}{$15 \%$ wax } & $61.59 \mathrm{aB}$ & $60.24 \mathrm{aA}$ & $60.32 \mathrm{aA}$ & $59.46 a A$ \\
\hline & \multicolumn{4}{|c|}{ Yolk (\%) } \\
\hline 0 (control) & $28.55 c A$ & $29.51 \mathrm{cA}$ & $32.50 \mathrm{bA}$ & $35.18 a A$ \\
\hline $12 \%$ wax & $26.72 \mathrm{bB}$ & $30.47 a A$ & 29.93aA & 29.82aB \\
\hline \multirow[t]{2}{*}{$15 \%$ wax } & $29.20 a A$ & $29.90 a A$ & $30.22 \mathrm{aA}$ & $30.52 \mathrm{aB}$ \\
\hline & \multicolumn{4}{|c|}{ Specific gravity $\left(\mathrm{g} \mathrm{cm}^{-3}\right)$} \\
\hline 0 (control) & $1.061 \mathrm{aB}$ & $1.050 \mathrm{bC}$ & $1.050 \mathrm{bC}$ & $1.050 \mathrm{bA}$ \\
\hline $12 \%$ wax & $1.071 \mathrm{aA}$ & $1.061 \mathrm{bB}$ & $1.054 \mathrm{cB}$ & $1.052 \mathrm{cA}$ \\
\hline $15 \%$ wax & $1.073 a A$ & $1.071 \mathrm{aA}$ & $1.063 \mathrm{bA}$ & $1.052 \mathrm{cA}$ \\
\hline
\end{tabular}

Means with different lowercase letters within a line are significantly different after Tukey test $(P<0.05)$. Means with different upper letters within a column are significantly different after Tukey test $(P<0.05)$. 
the albumen, into water and carbon dioxide. As a result, both molecules are transferred to the environment through the pores of the eggshell (Brake et al., 1997). Therefore, the rate of weight loss during storage is an important method to analyze egg quality.

The loss of the above-mentioned elements has undesirable consequences, including increased $\mathrm{pH}$ and reduced albumen viscosity, with consequent losses in egg weight (Caner \& Cansiz, 2008). The reduced albumen viscosity is associated with changes in its protein structure, including increased levels of clusterin and ovoinhibitor and a disorder of the ovalbumin structure (Sheng, Huang, Wang, Xu, Hammad, \& Ma, 2018). The extent of these changes is quantified by the Haugh unit, which associates albumen height with egg weight. Moreover, the continuous loss of moisture and carbon dioxide to the environment progressively increases the size of the air chamber, which reduces the specific gravity of eggs (Xu, Zhang, Lv, Chi, Wu, \& Shao, 2017). Coating eggs with carnauba wax resulted in less weight loss and, consequently, fewer variations in albumen structure, which led to higher Haugh unit values as well as higher values of specific gravity.

The breakdown of structural proteins in the vitelline membrane, coupled with differences in osmotic pressure, favors the movement of water from the albumen to the yolk, which reduces the integrity of the membrane (Akter, Kasim, Omar, \& Sazili, 2014). This fact is compatible with the reduction of albumen $\%$ and the increase of yolk \% during storage. Coating slows the rise in osmotic pressure by reducing the structural changes in the albumen, ensuring improved yolk quality during storage ( $X u$, Wang, Ren, \& Wu, 2018).

Eggs kept at room temperature showed lower internal quality during storage. The reduction of internal quality was lower in eggs kept under refrigeration, since lower temperatures minimize the occurrence of degradation reactions. Feddern, Prá, Mores, Nicoloso, Coldebella and Abreu (2017) observed that eggs stored for 9 weeks under refrigeration $\left(0-5^{\circ} \mathrm{C}\right)$ had a quality similar to those kept at room temperature $\left(20-35^{\circ} \mathrm{C}\right)$ for only 3 weeks, which demonstrates the influence of temperature on quality parameters of eggs. In addition to the interference with the quality parameters, higher storage temperatures can increase the penetration of bacteria into eggs (Wang \& Slavik, 1998). In this context, Menezes, Lima, Medeiros, Oliveira and Evêncio (2012) distinguished temperature and humidity as the two main factors affecting the egg quality during storage. The benefits of carnauba wax coating on egg quality parameters were evident in eggs kept at $25^{\circ} \mathrm{C}$. Therefore, carnauba wax demonstrated its potential for minimizing the main factors responsible for accelerating quality loss.

Besides favoring physical and chemical changes of both albumen and yolk, environmental and storage conditions can increase the internal contamination with undesirable microorganisms, which accelerates the degradation processes (Xu et al., 2017). Thus, coating with carnauba wax has proven to be an efficient barrier against microorganisms, maintaining a high internal egg quality. 


\section{Lipid oxidation in egg yolk}

There was no significant interaction $(P$ $>0.05$ ) between the factors on lipid oxidation (TBARS) of the egg yolk. However, the type of coating affected $(P<0.05)$ malondialdehyde concentrations. Uncoated and coated eggs showed similar lipid oxidation values regardless of the storage period. On the other hand, eggs coated with solutions containing 15\% wax showed less oxidation than eggs coated with $12 \%$ wax (Table 5).

\section{Table 5}

Effect of carnauba wax coating on thiobarbituric acid reactive substances (TBARS') values on egg yolk of laying hens stored for 28 days

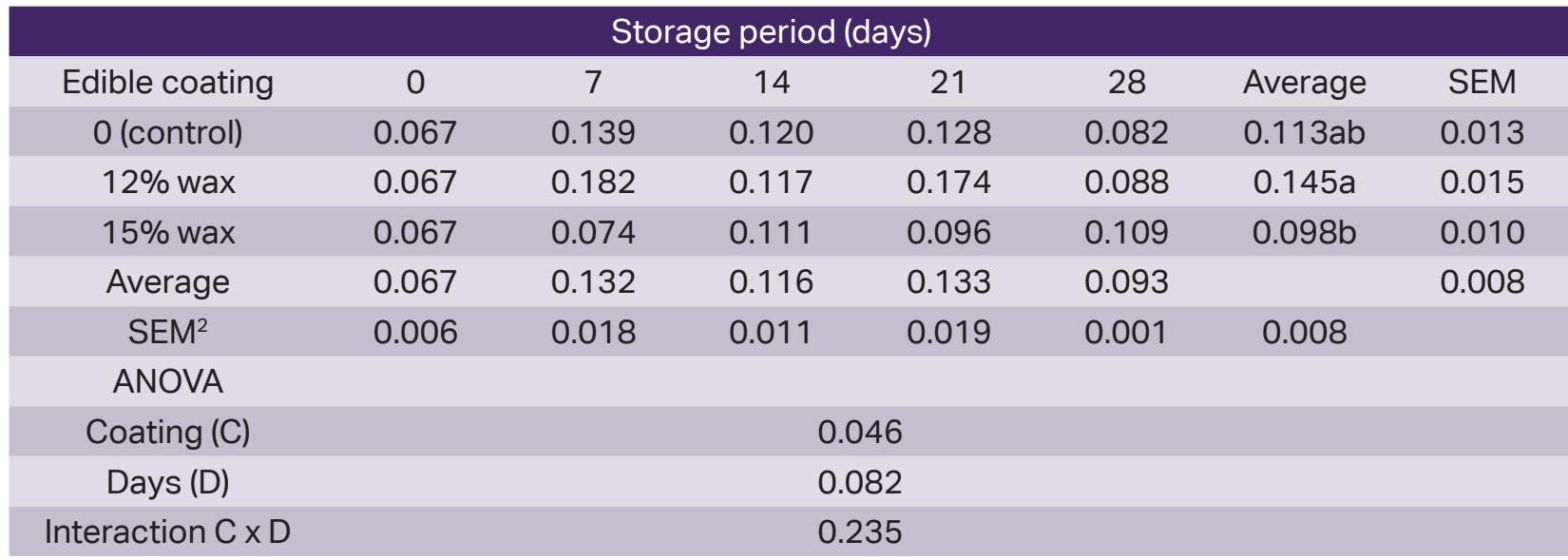

${ }^{1}$ Expressed in milligrams of malondialdehyde per kilogram of yolk (mgMAD. $\left.\mathrm{kg}^{-1}\right)$.

${ }^{2} \mathrm{SEM}=$ standard error of the mean.

Means with different letters within a column are significantly different after Tukey test $(P<0.05)$.

In addition to influencing the internal quality parameters of eggs, the coatings may be able to minimize the oxidation process of lipids in the yolk. Studies have shown that the control of gas exchange between the fruit and the environment results in less oxygen available for respiration and, thus, for metabolic processes (Bonilla, Atarés, Vargas, \& Chiralt, 2012), which delays lipid oxidation. Despite the reduction of weight loss in coated eggs, which demonstrated that carnauba wax was effective in sealing the pores of the eggshell and controlling the gas exchange between the internal and the external environment, it was not possible to observe a reduction in lipid oxidation in the yolks of coated eggs. This finding does not support our hypothesis about the influence of carnauba wax on lipid stability. The antioxidant capacity of carnauba wax is still controversial in the literature. Although it is evidenced that carnauba wax coating is a potential physical barrier, some studies have shown that extracts from wax powder have antioxidant and antifungal activities (Andrade et al., 2018). However, Zhang, Simpson and Dumont (2018) observed no change in 
antioxidant activity when using carnauba wax as an additive in gelatin films.

In a study on the use of mixed coatings containing carnauba wax to preserve freshcut apples, Chiumarelli and Hubinger (2014) reported increased respiration rates with increasing inclusion levels (\%) of wax. This result indicated that the concentration of this component might facilitate gas exchange with the environment. Despite these findings and considering that the coating in this experiment contained only carnauba wax, eggs coated with $15 \%$ carnauba wax had a lower amount of malondialdehyde compared with eggs coated with wax at $12 \%$, which were in turn similar to uncoated eggs.

\section{Conclusion}

The coating of commercial eggs with carnauba wax, both at concentrations of 12 and $15 \%$, was effective in maintaining their internal quality during storage at both storage temperatures $\left(10\right.$ and $\left.25^{\circ} \mathrm{C}\right)$. Eggs stored at $25^{\circ} \mathrm{C}$ had lower quality traits during storage compared with eggs kept under refrigeration. Coating eggs with wax did not minimize the oxidative processes in the egg yolk.

\section{Acknowledgments}

The authors are grateful to the brazilian institutions and research agencies CAPES and CNPq.

\section{Conflict of interest declaration}

The authors declared no conflict of interest.

\section{References}

Akter, Y., Kasim, A., Omar, H., \& Sazili, A. Q. (2014). Effect of storage time and temperature on the quality characteristics of chicken eggs. Journal of Food, Agriculture and Environment, 12(3-4), 87-92.

Almeida, D. S. de, Schneider, A. F., Yuri, F. M., Machado, B. D., \& Gewehr, C. E. (2015). Egg shell treatment methods effect on commercial eggs quality. Ciência Rural, 46(2), 336-341. doi: 10.1590/0103-8478 cr20140904

Andrade, L. B. da S., Julião, M. S. da S., Cruz, R. C. V., Rodrigues, T. H. S., Fontenelle, R. O. dos S., \& Silva, A. L. C. da. (2018). Antioxidant and antifungal activity of carnauba wax powder extracts. Industrial Crops and Products, 125, 220-227. doi: 10.1016/j. indcrop.2018.09.004

Bhattacharjee, D., \& Dhua, R. S. (2018). Enhancing postharvest storage life of pointed gourd (Trichosanthes dioica Roxb.) fruits with edible coatings. Journal of Pharmacognosy and Phytochemistry, 7(5), 607-611.

Bonilla, J., Atarés, L., Vargas, M., \& Chiralt, A. (2012). Edible films and coatings to prevent the detrimental effect of oxygen on food quality: possibilities and limitations. Journal of Food Engineering, 110(2), 208213. doi: 10.1016/j.jfoodeng.2011.05.034

Brake, J., Walsh, T. J., Benton, C. E., Petitte, J. N., Meijerhof, R., \& Peñalva, G. (1997). Egg Handling and Storage. Poultry Science, 76(1), 144-151. doi: 10.1093/ps/76.1.144

Brant, A. W., \& Shrader, H. L. (1958). Equipment and methods for measur ing egg quality. Washington, DC: Department of Agriculture. 
MAPA. (1990). Portaria no 1, de 21 de fevereiro de 1990. Normas gerais de inspeção de ovos e derivados. Ministério da Agricultura, Pecuária e Abastecimento.

Caner, C., \& Cansiz, O. (2008). Chitosan coating minimises eggshell breakage and improves egg quality. Journal of Science of Food and Agriculture, 88(1), 56-61. doi: 10.1002/jsfa.2962

Caner, C., \& Yüceer, M. (2015). Efficacy of various protein-based coating on enhancing the shelf life of fresh eggs during storage. Poultry Science, 94(7), 1665-1677. doi: 10.3382/ps/pev102

Chiumarelli, M., \& Hubinger, M. D. (2014). Evaluation of edible films and coatings formulated with cassava starch, glycerol, carnauba wax and stearic acid. Food Hydrocolloids, 38(2014), 20-27. doi: 10.1016/j. foodhyd.2013.11.013

Chung, S. H., \& Lee, K. W. (2014). Effect of hen age, storage duration and temperature on egg quality in laying hens. International Journal of Poultry Science, 13(11), 634636. doi: 10.3923/ijps.2014.634.636

Dou, H. (2004). Effect of coating application on chilling injury of grapefruit cultivars. HortScience, 39(3), 558-561. doi: 10.21 273/HORTSCI.39.3.558

Falguera, V., Quintero, J. P., Jiménez, A., Muñoz, J. A., \& Ibarz, A. (2011). Edible films and coatings: Structures, active functions and trends in their use. Trends in Food Science \& Technology, 22(6), 292-303. doi: 10.1016/j.tifs.2011.02.004

Feddern, V., Prá, M. C. de, Mores, R., Nicoloso, R. da S., Coldebella, A., \& Abreu, P. G. de. (2017). Egg quality assessment at different storage conditions, seasons and laying hen strains. Ciência e Agrotecnologia, 41(3), 322-333. doi: 10.1590/1413-7054 2017413002317

Figueiredo, T. C., Assis, D. C. S., Menezes, L. D. M., Oliveira, D. D., Lima, A. L., Souza, M. R.,... Cançado, S. V. (2014). Effects of packaging, mineral oil coating, and storage time on biogenic amine levels and internal quality of eggs. Poultry Science, 93(12), 31713178. doi: 10.3382/ps.2014-04268

Freitas, C. A. S. de, Sousa, P. H. M. de, Soares, D. J., Silva, J.Y.G. da, Benjamin, S. R., \& Guedes, M. I. F. (2019). Carnauba wax uses in food - A review. Food Chemistry, 291(2019), 3848. doi: 10.1016/j. foodchem.2019.03.133

Gole, V. C., Chousalkar, K. K., Roberts, J. R., Sexton, M., May, D., Tan, J., \& Kiermeier, A. (2014). Effect of egg washing and correlation between eggshell characteristics and egg penetration by various Salmonella typhimurium strains. PLoS One, 9(3), e90987. doi: 10.1371/ journal.pone.0090987

Hidalgo, A., Lucisano, M., Comelli, E. M., \& Pompei, C. (1996). Evolution of chemical and physical yolk characteristics during the storage of shell eggs. Journal of Agricultural and Food Chemistry, 44(6), 1447-1452. doi: 10.1021/jf950591q

Hutchison, M. L., Gittins, J., Walker, A., Sparks, N., Humphrey, T. J., Burton, C., \& Moore, A. (2004). An assessment of the microbiological risks involved with egg washing under commercial conditions. Journal of Food Protection, 67(1), 4-11. doi: 10.4315/0362-028X-67.1.4

Liu, Y. C., Chen, T. H., Wu, Y. C., Lee, Y. C., \& Tan, F. J. (2016). Effects of egg washing and storage temperature on the quality of eggshell cuticle and eggs. Food 
Chemistry, 211(2016), 687-693. doi: 10. 1016/j.foodchem.2016.05.056

Menezes, P. C. de, Lima, E. R. de, Medeiros, J. P. de, Oliveira, W. N. K. de, \& Evêncio, J., Neto. (2012). Egg quality of laying hens in different conditions of storage, ages and housing densities. Revista Brasileira de Zootecnia, 41(9), 2064-2069. doi: 10.1590/ S1516-35982012000900014

Molavi, H., Behfar, S., Ali Shariati, M., Kaviani, M., \& Atarod, S. (2015). A review on biodegradable starch based film. Journal of Microbiology, Biotechnology and Food Sciences, 4(5), 456-461. doi: 10.15414/ jmbfs.2015.4.5.456-461

Rose-Martel, M., Du, J., \& Hincke, M. T. (2012). Proteomic analysis provides new insight into the chicken eggshell cuticle. Journal of Proteomics, 75(9), 2697-2706. doi: 10.1016/j.jprot.2012.03.019

Samli, H. E., Agma, A., \& Senkoylu, N. (2005). Effects of storage time and temperature on egg quality in old laying hens. Journal of Applied Poultry Research, 14(3), 548553. doi: 10.1093/japr/14.3.548

Sharaf Eddin, A., Ibrahim, S. A., \& Tahergorabi, R. (2019). Egg quality and safety with an overview of edible coating application for egg preservation. Food Chemistry, 296(2019), 29-39. doi: 10.1016/j.food chem.2019.05.182

Sheng, L., Huang, M., Wang, J., Xu, Q., Hammad, H. H. M., \& Ma, M. (2018). A study of storage impact on ovalbumin structure of chicken egg. Journal of Food Engineering, 219(2018), 1-7. doi: 10.1016/j. jfoodeng.2017.08.028

Singh, S., Singh, B., \& Alam, T. (2019). Evaluation of shelf-life, antioxidant activity and nutritional quality attributes in carnauba wax coated eggplant genotypes. Journal of Food Science and Technology, 56(11), 4826-4833. doi: 10.1007/s13197-019-03 $944-x$

SAS Institute Inc. 2017. SAS User`s Guide: Statistics. Version 9.3 Edition. Cary, NC, SAS Inst. Inc.

Sun, C., Liu, J., Yang, N., \& Xu, G. (2019). Egg quality and egg albumen property of domestic chicken, duck, goose, turkey, quail, and pigeon. Poultry Science, 98(10), 4516-4521. doi: 10.3382/ps/pez259

Vyncke, W. (1970). Direct determination of the thiobarbituric acid value in trichoracetic acid extracts of fish as a measure of oxidative rancidity. Fette Seifen Anstrichmittel, 72(12), 1084-1087. doi: 10.1002/lipi. 19700721218

Wang, H., \& Slavik, M. F. (1998). Bacterial penetration into eggs washed with various chemicals and stored at different temperatures and times. Journal of Food Protection, 61(3), 276-279. doi: $10.4315 / 0362-028 x-61.3 .276$

Wardy, W., Torrico, D. D., No, H. K., Prinyawiwatkul, W., \& Saalia, F. K. (2010). Edible coating affects physico-functional properties and shelf life of chicken eggs during refrigerated and room temperature storage. International Journal of Food Science + Technology, 45(12), 2659-2668. doi: 10.1111/j.1365-2621.2010.02447.x

Wellman-Labadie, O., Picman, J., \& Hincke, M. T. (2008). Antimicrobial activity of the Anseriform outer eggshell and cuticle. Comparative Biochemistryand Physiology Part B: Biochemistry and Molecular Biology, 149(4), 640-649. doi: 10.1016/j. cbpb.2008.01.001 
Wilson, P. B. (2017). Recent advances in avian egg science: a review. Poultry Science, 96(10), 3747-3754. doi: 10.3382/ps/pex187

Yang, H., Li, X., \& Lu, G. (2018). Effect of carnauba wax-based coating containing glycerol monolaurate on decay and quality of sweet potato roots during storage. Journal of Food Protection, 81(10), 1643-1650. doi: 10.4315/0362-028X.JFP-18-017

Yuceer, M., \& Caner, C. (2014). Antimicrobial lysozyme-chitosan coatings affect functional properties and shelf life of chicken eggs during storage. Journal of the Science and Food Agriculture, 94(1), 153-162. doi: 10.1002/jsfa.6322

Xu, D., Wang, J., Ren, D., \& Wu, X. (2018). Effects of chitosan coating structure and changes during storage on their egg preservation performance. Coatings, 8(9), 317. doi: 10.3390/coatings 8090317
Xu, L., Zhang, H., Lv, X., Chi, Y., Wu, Y., \& Shao, H. (2017). Internal quality of coated eggs with soy protein isolate and montmorillonite: effects of storage conditions. International Journal of Food Properties, 20(8), 1921-1934. doi: 10.1080/10942912.2016.1224896

Zhang, Y., Simpson, B. K., \& Dumont, M. J. (2018). Effect of beeswax and carnauba wax addition on properties of gelatin films: a comparative study. Food Bioscience, 26(2018), 88-95. doi: 10.1016/j.fbio.2018. 09.011 
